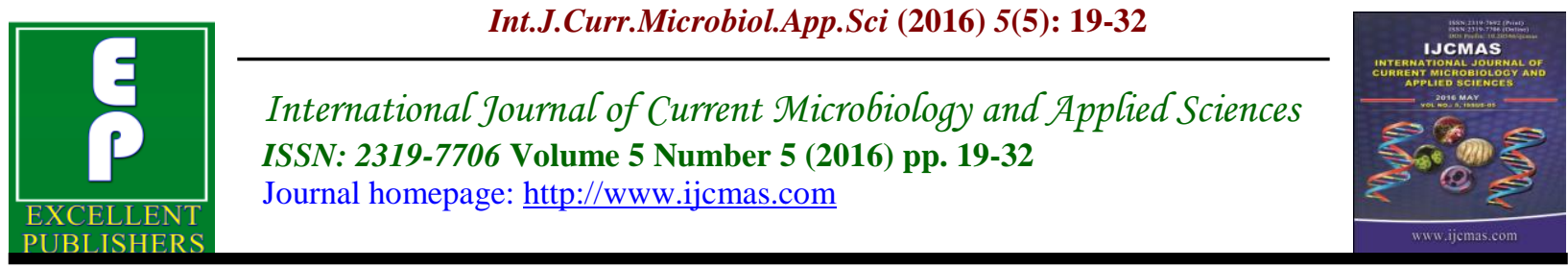

Original Research Article

http://dx.doi.org/10.20546/ijcmas.2016.505.003

\title{
Decolourization and Biological Treatment of Pulp and Paper Mill Effluent by Lignin-Degrading Fungus Aspergillus flavus Strain F10
}

\author{
Anand Barapatre and Harit Jha* \\ Department of Biotechnology, Guru Ghasidas Vishwavidyalaya (A Central University), \\ Bilaspur, Chhattisgarh, India.495009 \\ *Corresponding author
}

\begin{abstract}
A B S T R A C T
Keywords

Paper and pulp effluent, Aspergillus flavus, Decolourisation, Immobilization.

\section{Article Info}

Accepted:

06 April 2016

Available Online:

10 May 2016

A potential lignin-degrading fungal strain, identified as Aspergillus flavus strain F10 have been studied for the treatment of pulp and paper mill effluent. The results of this study revealed that A. flavus effectively reduced the colour and lignin content (in the term of total phenolic content). It reduces colourity up to 31-51\% and lignin content 39-61\% in ten days of incubation when used as a free form, while in immobilized condition it reduces more colourity and lignin content within 6 day of treatment. A significant reduction in color and lignin content by this fungus strain was observed after four days of incubation, indicating that fungus subsequently utilized chromophoric compounds thereby reducing lignin content and color. The toxicity of paper and pulp effluent was measured in the term of phytotoxicity. A high germination index of treated samples indicate that the treatment have reduced pollution load in effluent to low levels which are not toxic to plants.
\end{abstract}

\section{Introduction}

Pulp and paper milling are major industrial sectors using a huge amount of lignocellulosic raw materials and water during manufacturing processes, and releasing non-biodegradable organic materials, adsorbable organic halogens (AOX), chlorinated lignosulphonic acid, chlorinated resin, chlorinated phenol and chlorinated hydrocarbon in the effluent (Abhay Raj et al., 2007; Thompson et al., 2001; Buyukkamaci et al., 2010). In India, pulp and paper manufacturing is one of the eldest and leading industry, which produced about three million metric tons per annum finished products (Malaviya et al., 2007). Pulp and paper mill wastewater is produced from wood preparation, pulping process, pulp washing, screening, washing, bleaching, and paper machine and coating operations (Pokhrel et al., 2004). The generation of wastewater and the characteristics of pulp and paper mill effluent depend upon the type of manufacturing process adopted and the extent of recycling of water employed in the plant (Abhay Raj et al., 2007). These 
effluents contain many organic compounds, derived from lignin, which are responsible for their brown colour and also for increasing water temperature and decreasing photosynthesis rate of the phytoplanktonic community (Pedroza et al., 2007).

Most of these industries discharged their insufficiently treated waste into the rivers or streams, environmental impact of black liquor results not only from its chemical nature, but also from its dark coloration that reduces oxygen availability and negatively affects aquatic fauna and flora. All these organic compounds are toxic to aquatic organisms and resistant to microbial degradation, resulting in a decrease of the ecological value of natural systems surrounding the pulp mill (Clesceri et al., 1999; Ali et al., 2001). The raw wastewater from paper and board mills can be, potentially, very polluting. Indeed, a recent internal survey within the industry has shown that chemical oxygen demand (COD) values. Thus, wastewater from the industry needs to be treated to reduce any possible impacts on the aquatic environment (Thompson et al., 2001; Buyukkamaci et al., 2010).

The conventional treatment methods, such as aerated lagoons and activated sludge plants are ineffective in removing colour and phenolics. In most cases, this effluent (raw or treated) is discharged into the rivers, stream or other water bodies; resulting in high BOD, COD and also causing problems to community and environment. In many developing countries farmers are irrigating their crop plants with water bodies which might be severely exposed to industrial effluents. This leads to risks of bioaccumulation of toxicants as we move-up the food chain. Thus, it is important to treat the industrial effluents before their final discharge (Yang et al., 2008). Despite the fact that, wide range of physical and chemical treatment methods (electrocoagulation, ozonation, adsorption, advanced oxidation, and ultrafiltration) or combination of different methods in series are available for the treatment of effluent, but they are more energy intensive and suffer from residual effects. Thus, there is still a need for energy efficient, affordable and environment friendly technologies (Yang et al., 2008; Raj et al., 2014). In recent years the biotechnological approaches based biological treatment came in to scenario in present treatment systems, in which wide variety of microorganisms including fungi, actinomycetes, and bacteria as well as enzymes have been implicated but the recent research has been focused on with ligninolyic fungi (white rot and brown rot) due to their powerful lignin-degrading enzyme system (Malaviya et al., 2007; Kumar et al., 2012; Jha et al., 2013).

In the present study isolated ligninolytic fungus producers and studied their suitability for decolourisation of pulp and paper mill effluent. The immobilization of fungus also have an alternative mode of decolourisation of paper pulp effluent in contrast to long term use and storage.

\section{Materials and Methods}

\section{Chemicals}

All reagent used in experiments were of analytical grade and were purchased from Merck Pvt. Ltd. and Hi-Media Mumbai (India). Millipore Deionized Mili-Q water (Aliks, Millipore, Mumbai, India) were used for biochemical assay.

\section{Screening and Isolation of Fungi}

For the isolation of ligninolytic fungus soil samples were collected from Guru Ghasidas 
University campus, Bilaspur, C.G. Isolation of fungus was done in PDA medium with conventional dilution method. To screen the potent ligninolytic fungi, 32 isolated purified fungal strains were subjected to Bavendam's test (Bavendam, 1928) for initial screening and among them, a potent fungus F10 was considered for the further studies. Isolated fungi was purified and grown on optimized malt extract agar (MEA) medium and stored at $4{ }^{\circ} \mathrm{C}$.

\section{Identification of Fungus Strain}

The isolated potent lignin biodegrading fungus were identified by polyphasic approach (based on their microscopic, morphological characteristics (Holt et al., 1994) and by sequencing of their $18 \mathrm{~S}$ rRNA). Partial gene sequencing (including ITS1, 5S rRNA, ITS2 and partial 28S rRNA) of both fungus was performed by the commercial service provider, Chromous Biotech Pvt. Ltd., Bangalore, India. Strain identification was carried out by amplifying partial 18S rRNA using PCR with two primers ITS1 (5'TCCGTAGGTGAA CCTGCGG3') and ITS4 (3'TCCTCCGCT TATTGATATGC5').

The sequences of the partial 18S rRNA were compared with the $18 \mathrm{~S}$ rRNA sequence available in the public nucleotide databases at the National Center for Biotechnology Information (NCBI) by using their World Wide Web site (http://www.ncbi.nlm.nih.gov) to identify the approximate species. Multiple alignments of the sequences in this work and all reference sequences were performed using CLUSTAL W. The phylogenetic trees were constructed based on a neighborjoining algorithm in the MEGA 4.0 software program. The confidence values of branches in the phylogenetic tree were determined using bootstrap analysis based on 1000 interactions (Tamura et al., 2007).

\section{Decolourisation of the Paper Pulp Effluent}

\section{Effluent Origin and Physicochemical Characterization}

Two types of paper mill discharge effluents were obtained from Amlai paper plant (M.P., India). Sample A, wasproduced through chemical alkaline pulping process of hardwood (soda cook liquor, without any treatment) and sample B, was the soda cooked liquor with slight aerobic treatments. These effluents were collected in air tight $5 \mathrm{~L}$ bottle and stored at $4{ }^{\circ} \mathrm{C}$ till use. The physico-chemical characterization $[\mathrm{pH}, \mathrm{TS}$ (Total solid), TSS (total suspended solid), BOD (biological oxygen demand), COD (chemical oxygen demand)] were done according to standard method.

\section{Analytical Methods for Physic-chemical Characterization of Pulp Mill Discharge Effluent}

\section{Colourity Determination}

The colourity of cultures was determined according to the CPPA standard method (1974). According to this method the $\mathrm{pH}$ of effluent sample was adjusted to 7.6 with the help of $2 \mathrm{M} \mathrm{NaOH}$ and centrifuge at 10,000 g. The obtained clear supernatant was used for taking the absorbance at $465 \mathrm{~nm}$ against distilled water. The $\mathrm{A}_{465}$ values were transformed into colour units (CU) according to the formula

where $A_{1}$ is the absorbance of $500 \mathrm{CU}$ platinum-cobalt standard solution $\left(\mathrm{A}_{465}=0.132\right)$ and $\mathrm{A}_{2}$ is the absorbance of the wastewater sample (CPPA,1974). 


\section{Dissolved oxygen (DO)}

The DO was determined by the standard dilution technique according to method No. 5210 of APHA methods (Clesceri et al., 1999). The method consists of filling an airtight bottle of the specified size with sample to overflowing and incubating it at the specified temperature $\left(20^{\circ} \mathrm{C}\right)$ for 5 days. Dissolved oxygen concentration (DO) was measured before and after incubation. The final DO was computed from the difference between initial and final $\mathrm{DO}$ value.

\section{Chemical Oxygen Demand (COD)}

The COD of the effluent sample was determined by method No. 5220 of APHA methods (Clesceri et al., 1999). The effluent sample is refluxed in strongly acid solution with a known excess of $\mathrm{K}_{2} \mathrm{Cr}_{2} \mathrm{O}_{7}$. Oxygen consumed was measured against standards at $600 \mathrm{~nm}$ with a UV-visible spectrophotometer (UV-1800, Shimadzu, Japan).

\section{Solids (Total Solids and Total Suspended Solids)}

Total solids (TS) and total suspended solids (TSS) were estimated by method Nos. 2540$B$ and 2540-D respectively, of APHA methods (Clesceri et al., 1999). The sample was evaporated in a pre-weighted dish and dried to gain a constant weight in an oven at $103-105^{\circ} \mathrm{C}$. The increase in weight over that of an empty dish represents TS. For estimation of TSS, the effluent sample was filtered through glass fibre filter and the residue retained on filter was dried up to a constant weight at $103-105^{\circ} \mathrm{C}$.

\section{Other Biochemical Analysis}

Total carbohydrate (by Anthron), reducing sugar (by DNS method) and total phenolic content (by Folin-Denis method) content were also quantified before and after
Decolourisation experiments (Hedge et al., 1962; Miller, 1959; Barapatre et al., 2015).

\section{Decolourisation Conditions}

A total of $100 \mathrm{~mL}$ mineral salt medium were taken in a $250 \mathrm{~mL}$ flask and 3 bores of 7 day old fungal culture were inoculated in it. The $100 \mathrm{~mL}$ mineral salt medium consist of $80 \%$ $(\mathrm{v} / \mathrm{v})$ total pulp effluent and $20 \%$ of mineral salt medium $\left(\mathrm{KH}_{2} \mathrm{PO}_{4} 0.2 \% ; \mathrm{MgSO}_{4} .7 \mathrm{H}_{2} \mathrm{O}\right.$ $0.05 \% ; \mathrm{CaCl}_{2} .2 \mathrm{H}_{2} \mathrm{O} \quad 0.01 \% \quad(\mathrm{w} / \mathrm{v})$; mineral salt solution $1 \mathrm{~mL} / \mathrm{L})$ supplemented with a carbon source (D-glucose) at a concentration of $0.5 \%(\mathrm{w} / \mathrm{v})$ and a nitrogen source $(0.3 \%$ w/v, ammonium nitrate). The flasks were inoculated at $28{ }^{\circ} \mathrm{C}$ in static and shaking condition (120 rpm). Uninoculated media serve as a control. The $5 \mathrm{~mL}$ sample was withdrawn at every 2 day interval up to 10 days to determine the decolouration.

\section{Microbial Decolourisation of Paper Pulp Effluent by Immobilized Fungus}

Aspergillus flavus F10 was entrapped in Calcium-alginate polymer beads using a method based on that described by Enayatzamir et al. (2010). Five millilitres of mycelia suspension was mixed with $100 \mathrm{~mL}$ of sodium alginate $2.1 \% \quad(\mathrm{w} / \mathrm{v})$ under shaking. The final concentration of alginate in the beads was $2 \%$. The mixture was dropped by means of a syringe into a $\mathrm{CaCl}_{2}$ solution $(3 \% \mathrm{w} / \mathrm{v})$ under shaking. To minimize cellular leaking, a method of gel re-coating was used. After $30 \mathrm{~min}$, the beads were collected from the solution and washed with distilled water and placed into a solution of sodium alginate $0.5 \%(\mathrm{w} / \mathrm{v})$ for 5-10 min (this makes it possible for the diffusion of the $\mathrm{Ca}^{+2}$ from the beads to produce the gelification on the bead surface of a second alginate cover). After that, the beads were washed with sterile distilled water and left to harden for $30 \mathrm{~min}$ into a $3 \%(\mathrm{w} / \mathrm{v})$ solution of $\mathrm{CaCl}_{2}$. Finally, the beads were washed with $0.7 \%$ (w/v) $\mathrm{NaCl}$. 
Alginate beads were produced under sterile conditions and hence, all solutions involved were autoclaved until used.

\section{Phytotoxicity Evaluation by Seed Germination Tests}

The phytotoxicity study was carried out to check the toxicity the treated effluent. Experiment was done at room temperature in relation to germination of Phaseolus mungo (15 seeds). Seeds were sterilized with $10 \%(\mathrm{v} / \mathrm{v})$ sodium hypochlorite for 20 min to prevent any microbial contamination. Germination of seeds were done by watering separately $5 \mathrm{~mL}$ treated and untreated pulp effluent per day. Control set was carried out using distilled water at the same time. All results were recorded in terms of \% germination, length of plumule (shoot) and radicle (root) was recorded after 7 days and the germination index (GI) was calculated.

The germination index (GI) was calculated as follows:

$$
\mathbf{G I}=\frac{100 \times(\mathbf{G} \times \mathbf{L})}{(\mathbf{G c} \times \mathbf{L} \mathbf{c})}
$$

where $\mathrm{G}$ and $\mathrm{L}$ are the germination and radicle growth of the seeds germinated in the tested solution, respectively, and $G_{C}$ and $\mathrm{L}_{\mathrm{C}}$ the germination and radicle growth of the seeds in the control (distilled water), respectively. According to Zucconi et al., (1981), GI values below $50 \%$ are considered to be indicative of a high toxicity, values between $50-80 \%$ represent a slight toxicity, and when the GI is higher than $80 \%$, no phytotoxicity is considered.

\section{Result and Discussion}

\section{Isolation of Test Strain}

All of the 32 morphologically different fungal isolates exhibited a different ability to degrade lignin when tested on tannic acid amended media. Eighteen fungal strains shows positive reactions in which fungus, named Aspergillus flavus strain F10, the potent fungus (form highest diameter of dark zone) was selected for the decolouration of pulp and paper mill effluent studies. Bavendam medium were used for the selection of the ligninolytic organism. In early several authors revealed that the incorporation of tannic acid in the culture medium provide preliminary test to detect the production and presence of ligninolytic enzymes (Thormann et al., 2002; Kausar et al., 2010). Polyphenol oxidases includes a group of the enzymes (laccase, lignin peroxidase, manganese dependent and independent peroxidase and versatile peroxidases) which catalyzed the reaction between polyphenol and molecular oxygen, and form the dark brown quinone complexes, a positive reaction of the degradation of the phenolic compound like lignin, gallic acid and tannic acid. The polyphenol oxidase is mainly produced by the ligninolytic fungus produce a dark colour zone around the mycelia growth in the Bavendam medium (Thormann et al., 2002).

\section{Microscopic Observation of Fungal Strain F10 and Strain Identification by $18 S$ rRNA Sequencing}

Microscopic observations of fungal appearance: mycelium composed of hyaline, branched, septate, smooth-walled hyphae. Conidiophores are smooth-walled and brittle, hyaline to pale brown; conidial heads are loosely radiate; conidiogenous cells biseriate; vesicles spathulate to subclavate; metulaes and phialides covering from $60 \%$ to almost the entire vesicle; conidia are globose, blue green, more or less roughwalled. The result of partial 18S rRNA sequence alignment based on BLAST analysis revealed that the isolated fungus strain F10 were shows high homology with (> 98\%) Aspergillus flavus. The sequence 
were deposited in the NCBI Genomic Bank nucleotide database and have been assigned accession numbers KC911631.1 (F10). Phylogenetic tree analysis were shown in Fig. 1.

\section{Characterization of Waste Effluent}

The paper pulp mill effluent used in the decolourisation experiment had a dark brown colour and turbid colloidal appearance with a large amount of solid particulate matter. The analysis of effluent were done by different parameters showing high TS, TSS, pH, COD, and colourity. The observed values were presented in Table 1. From the observation table it was clearly seen that the sample B (biologically treated) having low $\mathrm{pH}$, TS, TSS, COD, DO and CU than sample A (non-treated).
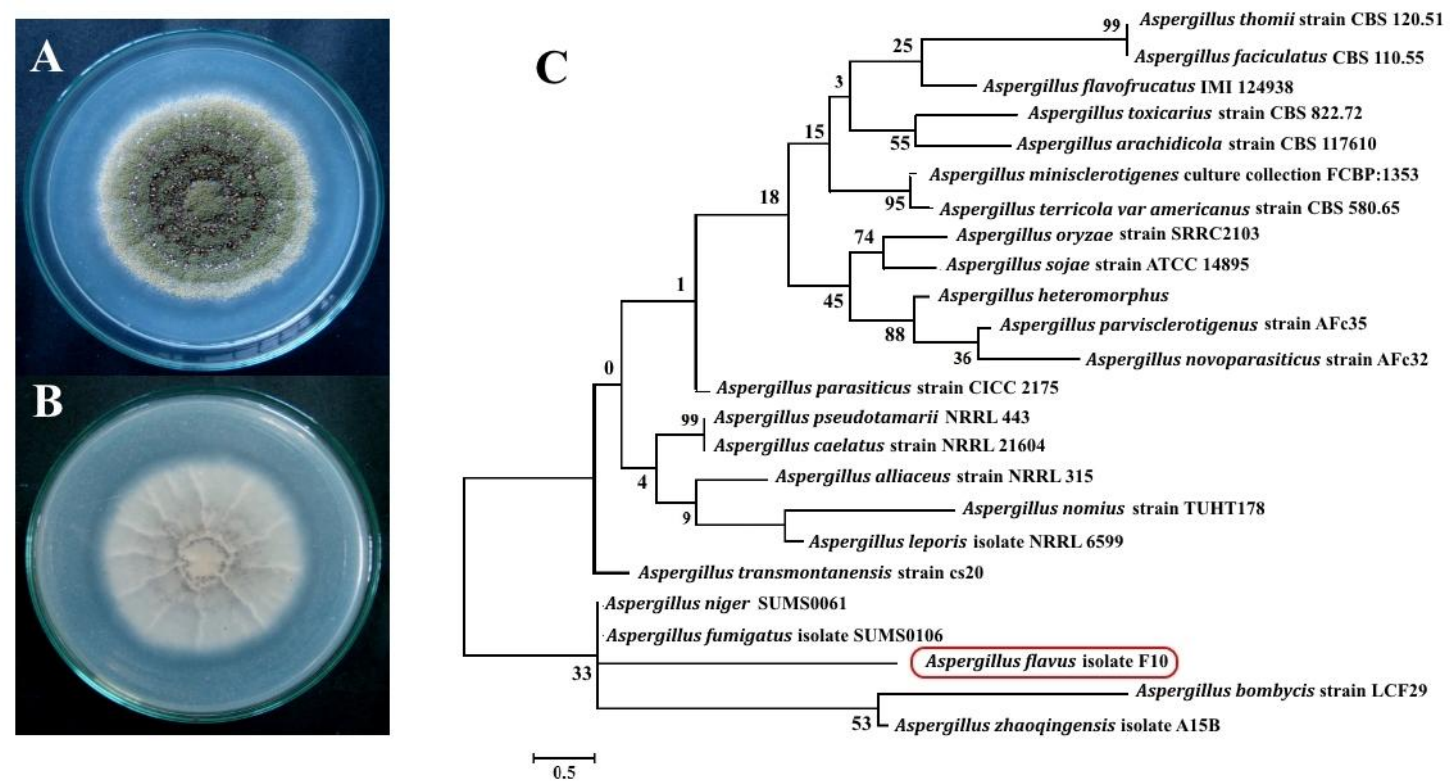

Fig.1 A \& B Front and back view of selected fungus Aspergillus flavus (F10).

(C) Phylogenetic tree of A. flavus F10

Table 1: Characteristic of paper pulp effluent

\begin{tabular}{lll}
\hline Parameter & Sample A & Sample B \\
\hline $\mathrm{Ph}$ & 10.28 & 7.44 \\
$\mathrm{TS}(\mathrm{mg} / \mathrm{L})$ & 6410.00 & 1860.00 \\
$\mathrm{TSS}(\mathrm{mg} / \mathrm{L})$ & 910.00 & 130.00 \\
$\mathrm{COD}(\mathrm{mg} / \mathrm{L})$ & 253.20 & 174.40 \\
$\mathrm{DO}(\mathrm{mg} / \mathrm{L})$ & 28.00 & 32.00 \\
$\mathrm{CU}$ & $5029.00 \mathrm{U}$ & $1853.50 \mathrm{U}$ \\
\hline
\end{tabular}


Decolourisation of Paper Pulp Effluent by

\section{A. flavus F10}

The white and brown rot fungi are unique among eukaryotes for having capability to degradation of lignin; and the lignin degradation is a secondary metabolic process in which they do not use lignin as a primary carbon source for their growth (Murugesan, 2003). Lignin is one of the major component which was the main cause of the colourity of pulp mill effluent. The decolourization of both effluent were done by A. flavus F10 and percent colour decolourisation were shown in Table 2 . Results depicted that there was a change in the reducing in colour unit in both type of treatment conditions (static and shaking), which confirm that the decolourisation was also influenced by culture condition. It was found that the maximum decolourisation occurred in sample A was $33.68 \%$ in the shaking condition as compared to $29.39 \%$ in static condition. The decolourisation in the effluent was also high for in shaking condition for sample B (66.32\%)in comparison to static condition which is $61.91 \%$.

Table.2 Percent (\%)colour removal of paper pulp effluent treated by A.flavus F10

\begin{tabular}{lllll}
\hline & \multicolumn{3}{c}{ Percent (\%) colour removal } \\
\cline { 2 - 5 } Day & $\begin{array}{l}\text { Sample A } \\
\text { static }\end{array}$ & $\begin{array}{l}\text { Sample A } \\
\text { shaking }\end{array}$ & $\begin{array}{l}\text { Sample B } \\
\text { static }\end{array}$ & $\begin{array}{l}\text { Sample B } \\
\text { shaking }\end{array}$ \\
\hline 0 & 0 & 0 & 0 & 0 \\
2 & 5.46 & 5.09 & 10.32 & 13.48 \\
4 & 11.35 & 13.69 & 33.33 & 35.75 \\
6 & 17.45 & 20.38 & 40.90 & 46.15 \\
8 & 27.74 & 30.76 & 54.06 & 58.60 \\
10 & 29.39 & 33.68 & 61.91 & 66.32 \\
\hline
\end{tabular}

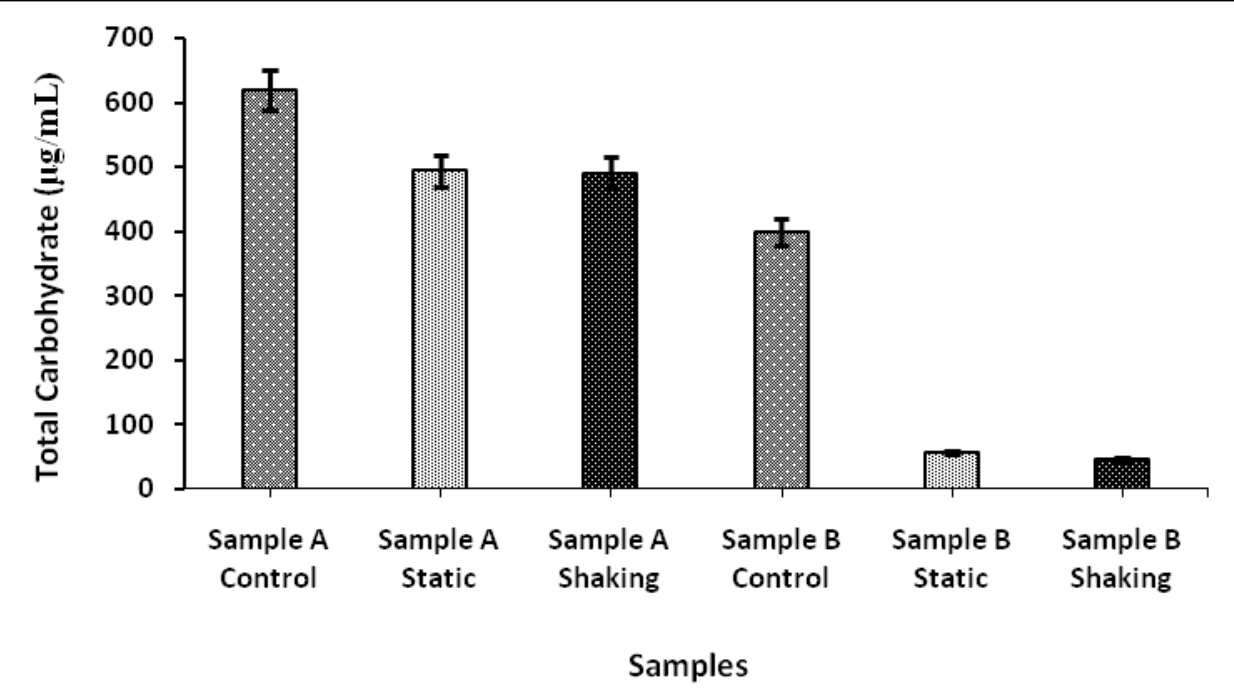

Fig.2 Total carbohydrate content of control and treated paper and pulp effluent 


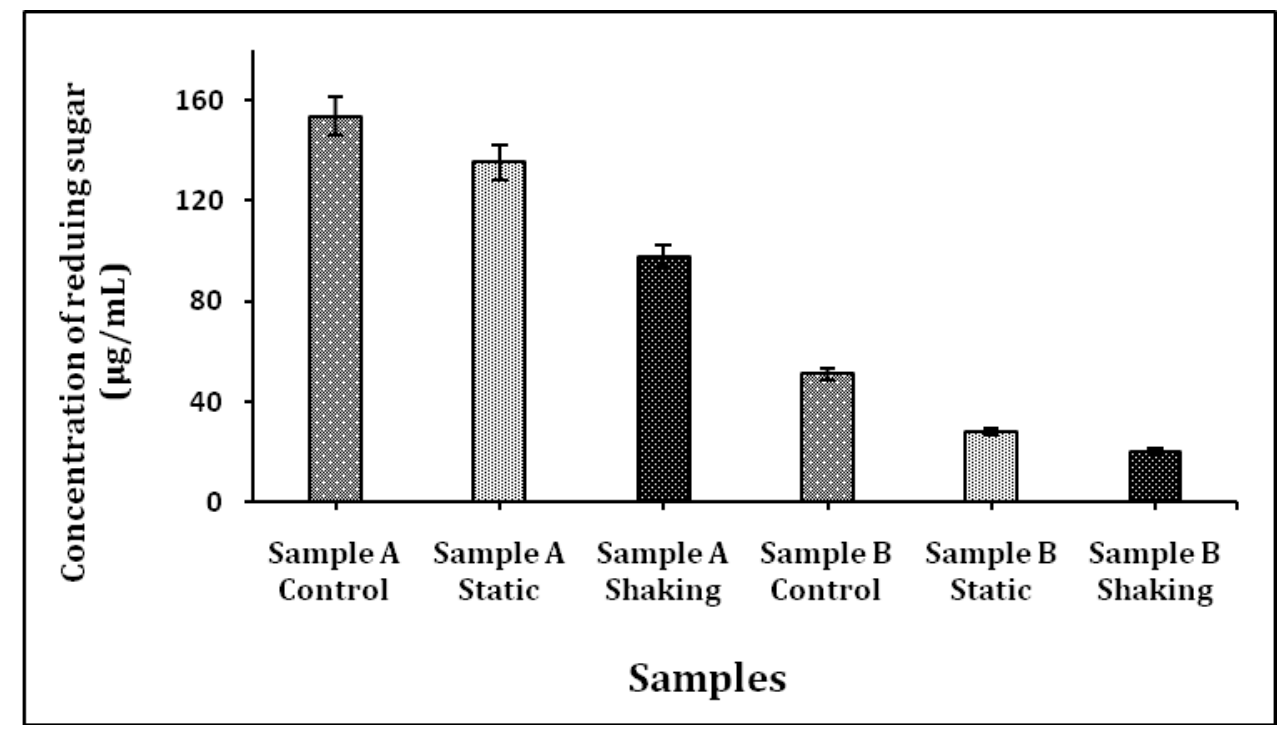

Fig.3 Reducing sugar content of control and treated paper and pulp effluent

\section{Biochemical Analysis of Control and Treated Paper and Pulp Effluent}

\section{Quantification of Total Sugar through Anthrone test}

After treatment (at day 10) by A.flavus F10, the total sugar content was decreased in treated sample as compare to their control (Fig. 2). The decrease in total sugar content was more in sample $\mathrm{B}$ as comparison to sample A. The incubation conditions did not affect the utilization of the carbohydrate in treated samples.

Glucose was added during the biological treatment of effluent, which was used as a supportive carbon as well as energy source for rapid growth of fungus and degrade the phenolic or aromatic compounds present in the effluent. The study shows that the fungus utilized the added glucose as a primary carbon source. The efficient decolourization of paper pulp effluent in the presence of glucose was also reported in several previous studies (Ragunathan et al., 2004; Prasongsuk et al., 2009; Singhal et al., 2009).

\section{Quantification of Reducing Sugar}

Result were presented in Fig. 3 indicatedthat both types of treated samples (shaking and static) the amount of final reducing sugar was significantly low. Among treated samples, the utilization of reducing sugar were high in shaking condition as compare to static.

\section{Total Polyphenol}

Result presented in Fig. 4 indicate that the test fungus reduce the polyphenolic content in both type of treatment condition (shaking and static). The amount of final polyphenolic was significantly low in treated sample as compared to both control samples. The reduction in polyphenolic content is the clear sign that the fungus utilize polyphenol efficiently. Fungus ligninolytic enzymatic system reduced these polyphenol into small monomeric fractions, which were ultimately consumed by the fungus as a carbon source (Barapatre et al., 2015). In the static condition the \% reduction of lignin and carbohydrate content was high as compare to shaking condition, 
which might be due to the production of high amount of ligninolytic enzymes. According to the Gorska et al., (2014) a higher production of the ligninolytic enzymes under agitation conditions may be the result of varied resistance of fungal hyphae to mechanical damage caused by shaking the culture as well as different requirements regarding oxygen and $\mathrm{CO}_{2}$ concentration in the mycelium growth phase.

\section{Decolourisation of Paper Pulp Effluent by Immobilized A.flavus F10 into Alginate Bead}

The experiment result showed the decrease in the colour unit of effluent samples after treatment with the fungus. The percent decolourisation is shown in Table 3. It was found that the maximum decolourisation of 49.58\% occurred in sample A treated by immobilized fungus whereas in sample B it was $93.11 \%$. The percent decolourisation was high inimmobilized fungus sample in comparison to free fungus cells. The immobilization of microbial cell on the solid support or entrapment play an important role in the treatment of industrial waste water. The alginate immobilized fungus were also used for the decolourisation of paper and pulp effluent (Jha et al., 2002; OrtegaClemente et al., 2009). Calcium-alginate beads with and without fungus were prepared by the liquid curing method in the presence of $\mathrm{Ca}^{2+}$ ions. Ca-alginate was used as a support material for the immobilization of the A. flavus (F10). The advantage of immobilized fungus was the repetitive batch decolourisation and long term preservation. Data of the study indicated that more efficient treatment was achieved by the immobilized fungi as compare to free cells. Jha et al., (2002) and Ortega-Clemente et al., (2009) found that immobilized fungus efficiently remove/degrade the lignin and reduce the colourity of pulp effluent.

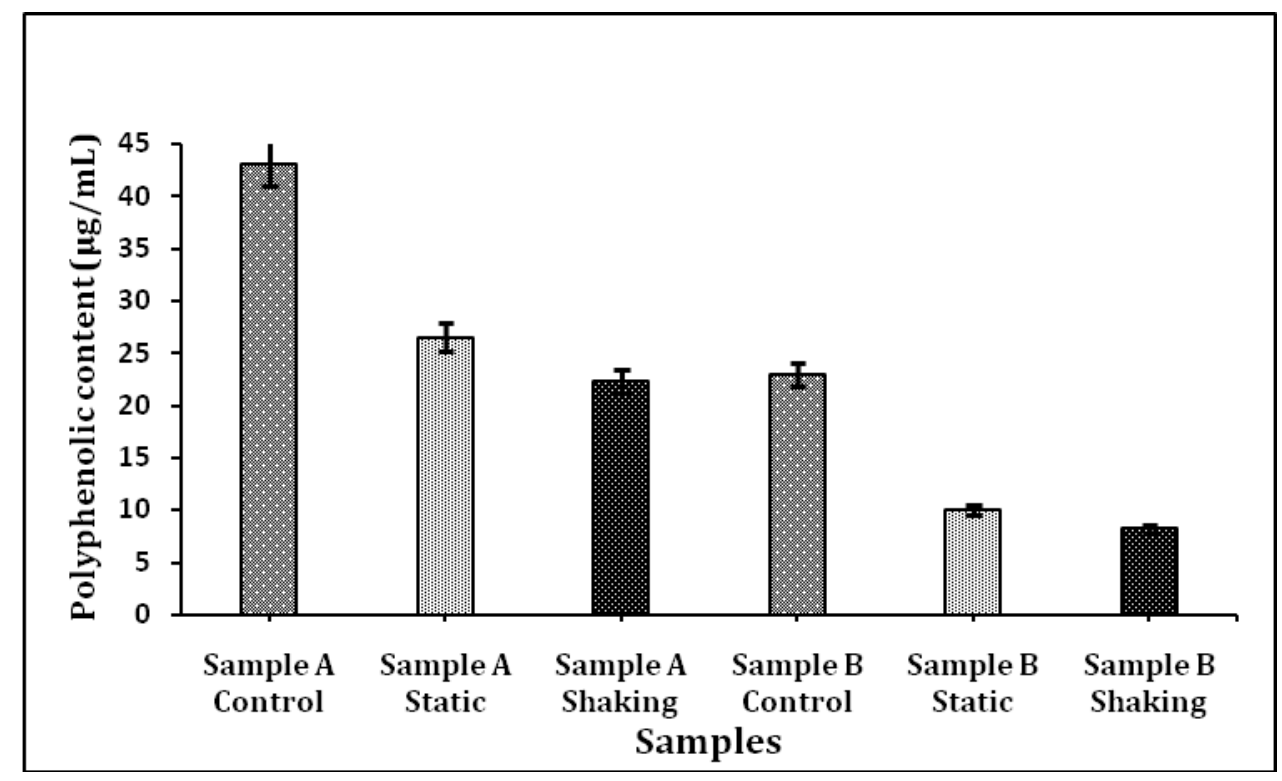

Fig.4 Total polyphenol content of control and treated paper and pulp effluent 


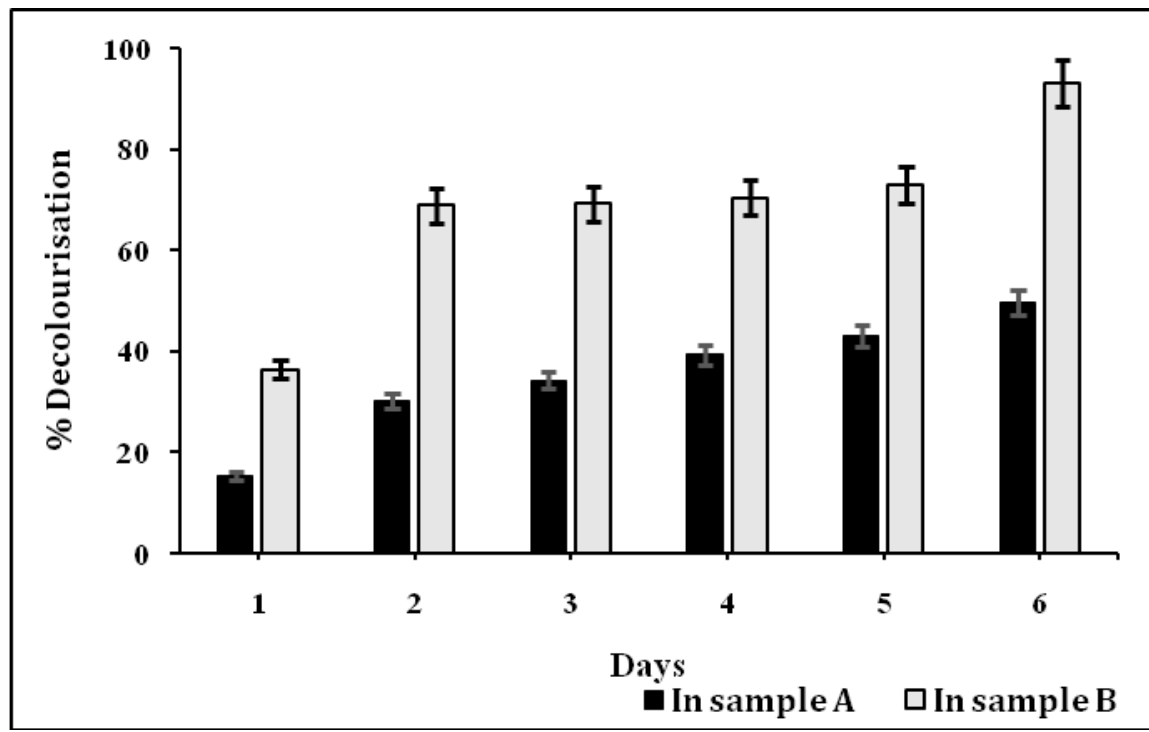

Fig.5 Colour decolorization of paper pulp effluent using Immobilized A.flavus F10 into alginate bead

Table.3 Phytotoxicity analysis

\begin{tabular}{llllll}
\hline Sample & $\begin{array}{l}\text { Length of } \\
\text { shoot }(\mathbf{c m})\end{array}$ & $\begin{array}{l}\text { Length of } \\
\text { root }(\mathbf{c m})\end{array}$ & $\begin{array}{l}\text { Germination } \\
\text { \% }\end{array}$ & $\begin{array}{l}\text { Root: shoot } \\
\text { ratio }\end{array}$ & $\begin{array}{l}\text { GI index } \\
(\%)\end{array}$ \\
\hline Control & 14.50 & 8.60 & 100 & $1: 1.69$ & - \\
$\begin{array}{l}\text { Sample A } \\
\text { untreated }\end{array}$ & 3.80 & 2.30 & 26.66 & $1: 1.65$ & 7.04 \\
$\begin{array}{l}\text { Sample A } \\
\text { treated static }\end{array}$ & 10.66 & 7.20 & 73.66 & $1: 1.48$ & 61.67 \\
$\begin{array}{l}\text { Sample A } \\
\text { treated shaking }\end{array}$ & 10.75 & 6.7 & 86.66 & $1: 1.6$ & 67.51 \\
$\begin{array}{l}\text { Sample B } \\
\text { untreated }\end{array}$ & 10.68 & 6.0 & 80.00 & $1: 1.78$ & 55.81 \\
$\begin{array}{l}\text { Sample B } \\
\text { static treated }\end{array}$ & 12.22 & 5.80 & 100.00 & $1: 2.11$ & 67.44 \\
$\begin{array}{l}\text { Sample B } \\
\text { shaking treated }\end{array}$ & 13.67 & 7.70 & 100.00 & $1: 1.77$ & 89.53 \\
\hline
\end{tabular}

\section{Seed Germination Test}

The result of phytotoxicity test of treated and non-treated paper and pulp mill effluent was verified on Phaseolus mungo seed germination test on different parameter like the percentage of seed germination, rootshoot length and root shoot ratio and presented in Table 3. It was observed that Phaseolus mungo when grown on distilled water (control) and treated effluent sample showed a high percentage of germination, and a high shoot and root growth. On the other hand, the Phaseolus mungo seeds grown on untreated effluent showed low germination percentage, high growth inhibition and less root, shoot length as compared to the seeds grown on control. As expected, GI was low for the untreated 
sample and the sample A was most toxic for the growth of Phaseolus mungo in present study. The sample which treated in shaking condition show high GI (67.51 and 89.53\%) index in comparison to sample treated in static condition (61.67 and 67.44\%). The poor germination and growth of seeds on raw effluent were due to high toxicity and high pollution load associated with the effluent, which was the one of the reason due to which untreated sample $A$ have lowest GI index. Whereas sample B shaking having highest GI index $(\approx 90 \%)$ indicate that the sample having no phytotoxicity, while all other samples having GI index (50$90 \%$ ) indicates low phytotoxicity. These results indicate that the biological treatment have reduced pollution load in effluent and reduce the possible toxicant to low levels. The reduction of the toxicity of pulp effluent by biological treatment was also successfully reported (Malaviya et al., 2007, Raj et al., 2014).

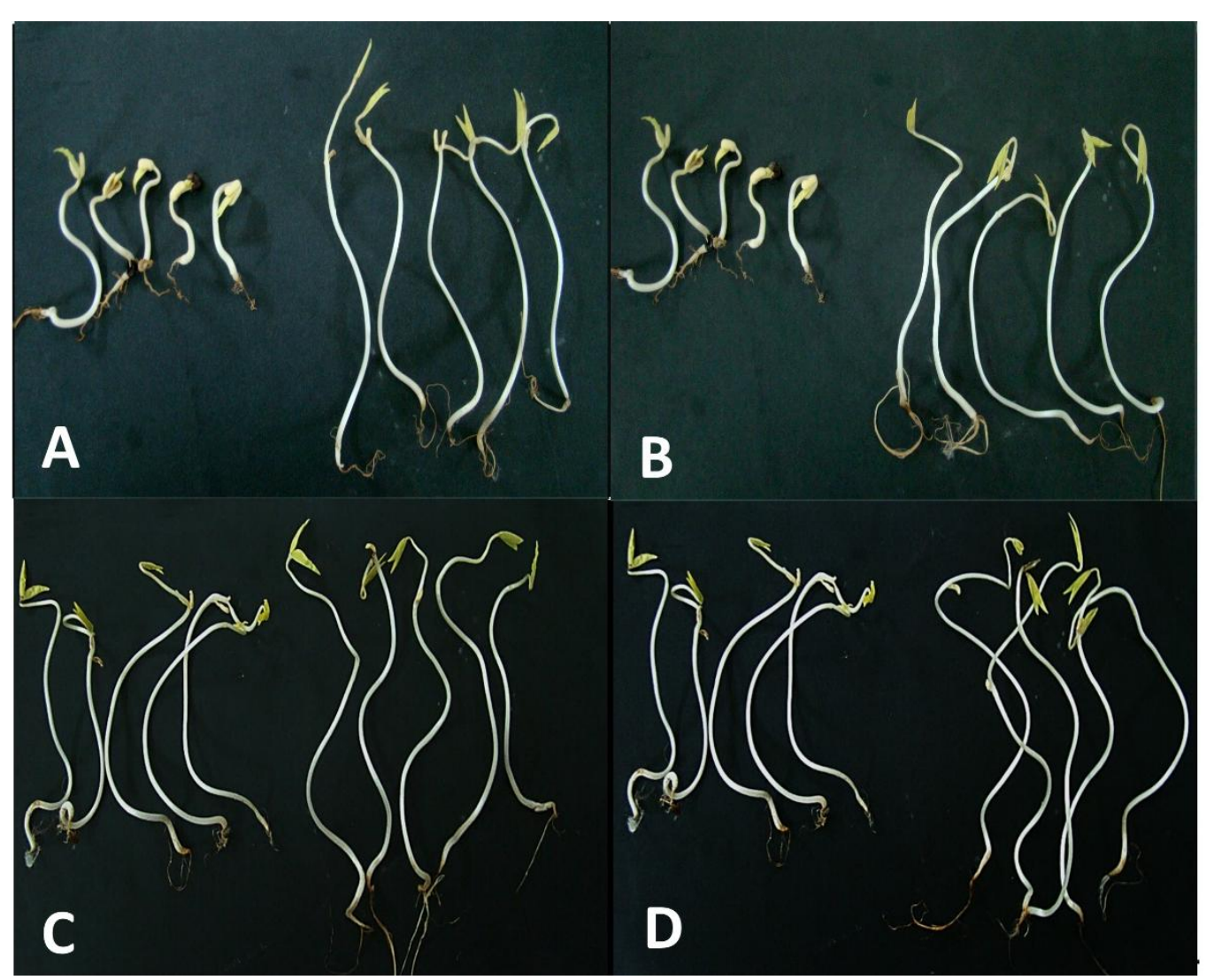

Fig. 6: (A) Untreated Sample A (left) with treated sample A (right) in static condition. (B) Untreated Sample A (left) with treated sample A (right) inshaking condition. (C) Untreated Sample B (left) with treated sample B (right) in staticcondition. (D) Untreated Sample B (left) with treated sample B (right) in shaking condition.

Pulp and paper industry is one of the most water-dependentindustries, which utilize about $50 \mathrm{~m}^{3}$ water to produce a ton of paper (Buyukkamaci et al., 2010). Effluents of the pulp and paper industry contain a number of toxic compounds and may cause deleterious environmental impacts upon direct discharge to receiving waters (Catalkaya et al., 2007). Paper and pulp effluent comprises an offensive colour due to the presence of 
lignin and its derivatives and also distort the water quality which is not only aesthetically unacceptable, but also inhibit the photosynthesis process in the stream due to absorbance of sunlight. This reduction in the sunlight amount will leads to a great adverse effects on the aquatic ecosystem, and as well as in the growth of primary consumers, and these will ultimately affect the secondary and tertiary consumers (Murugesan, 2003).

In conclusion, the results indicate that the utilization of Apsergillus flavus F10 is suitable for the Decolourisation and polyphenolic groups removal from soda pulping effluentsin the presence of a carbon source. The overall removal efficiencies of Aspergillus flavus $F 10$ for reduction in the colour of effluent were observed after $10^{\text {th }}$ and $6^{\text {th }}$ day of incubation in free and immobilized form. Further, the toxicity of treated effluent was significantly reduced and the treated effluent was able to support the growth of Phaseolus mungo even in undiluted form suggesting improved properties of biologically treated effluent.

\section{Reference}

Barapatre, A., Aadil, K.R., Tiwary, B.N., Jha, H. 2015. In vitro antioxidant and antidiabetic activity of biomodified lignin from Acacia nilotica, Int. J. Biol. Macromol., 75: 81-89.

Ortega-Clemente, A., Caffarel-Méndez, S., Ponce-Noyola, M.T., Barrera-Córtes, J., Poggi-Varaldo, H.M. 2009. Fungal post-treatment of pulp mill effluents for the removal of recalcitrant pollutants, Biores. Technol., 100: 1885-1894.

Raj, A., Reddy, M.M.K., Chandra, R., Purohit, H.J., Kapley, A. 2007. Biodegradation of kraft-lignin by Bacillus sp. isolated from sludge of pulp and paper mill, Biodegradation, 18: 783-792.

Raj, A., Kumar, S., Haq, I., Singh, S.K. 2014. Bioremediation and toxicity reduction in pulp and paper mill effluent by newly isolated ligninolytic Paenibacillus sp., Ecol. Eng., 71: 355362.

Singhal, A., Thakur, I.S. 2009. Decolourization and detoxification of pulp and paper mill effluent by Cryptococcus sp., Biochem. Eng. J., 46: 21-27.

Pedroza, A.M., Rodolfo, M., Alonso-Vante, N., Rodríguez-Vásquez, R. 2007 Sequential treatment via Trametes versicolor and $\mathrm{UV} / \mathrm{TiO} 2 / \mathrm{RuxSey}$ to reduce contaminants in waste water resulting from the bleaching process during paper production, Chemosphere, 67: 793-801.

Yang, C., Cao, G., Li, Y., Zhang, X., Ren, H., Wang, X., Feng, J., Zhao, L., Xu, P. 2008. A constructed alkaline consortium and its dynamics in treating alkaline black liquor with very high pollution load, PLoS One, 3: e3777.

CPPA. 1974. Technical section standard method H5P. Canadian Pulp and Paper Association, Montreal.

Pokhrel, D., Viraraghvan, T. 2004. Treatment of pulp and paper wastewater - A review, Sci. Total Environ., 333: 37-58.

Wong, D.W.S. 2009. Structure and action mechanism of ligninolytic enzymes, Appl. Biochem. Biotechnol., 157: 174209.

Górska, E.B., Jankiewicz, U., Dobrzyński, J., Gałązka, A., Sitarek, M., Gozdowski, D., Russel, S., Kowalczyk, P. 2014. Production of Ligninolytic Enzymes by Cultures of White Rot Fungi, Pol. J. Microbiol., 63: 461-465. 
Catalkaya, E.C., Kargi Color, F. 2007. TOC and AOX removals from pulp mill effluent by advanced oxidation processes: A comparative study, $J$. Hazard. Mat. B., 139: 244-253.

Zucconi, F., Forte, M., Monaco, A., Bertoldi, M.D. 1981. Biological evaluation of compost maturity, Bio Cycle, 22: 27-29.

Miller, G.L. 1959. Use of dinitrosalicylic acid reagent for determination of reducing sugar. Anal. Chem.,31: 426428.

Jha, H., Patil, M. 2013. Biopulping of sugarcane bagasse and decolorization of kraft liquor by the laccase produced by Klebsiella aerogenes NCIM 2098, Malays. J. Microbiol., 9: 301-307.

Jha, H., Sapre, M., Dhake, J.D., Patil, M.B. 2002. Decolorization of black liquor by sequential treatment with $P$. Chryrosprium and $K$. aerogenes, Asian J. Microbiol. Biotechnol. Environ. Sci., 4: 457-463.

Kausar, H., Sariah, M., Saud, H.M., Alam, M.Z., Ismail, M.R. 2010. Development of compatible lignocellulolytic fungal consortium for rapid composting of rice straw, Int. Biodeterior. Biodegradation, 64: 594600.

Hedge, J.E., Hofreiter, B.T. 1962. In: Carbohydrate Chemistry, 17 (Eds. Whistler R.L. and Be Miller, J.N.), Academic Press, New York.

Enayatzamir, K., Alikhani, H.A., Yakhchali, B., Tabandeh, F., Rodríguez-Couto, S. 2010. Decolouration of azo dyes by Phanerochaete chrysosporium immobilised into alginate beads, Environ Sci. Pollut. Res., 17: 145-153.

Murugesan, K. 2003. Bioremediation of paper and pulp mill effluents, Indian J. Exp. Biol., 41: 1239-1248.

Tamura, K., Dudley, J., Nei, M., Kumar, S. 2007. MEGA4: molecular evolutionary genetics analysis (MEGA) software version 4.0, Mol. Biol. Evol., 24: 1596-1599.

Clesceri, L.S., Greenberg, A.E., Eaton, A.D. 1999. Standard Methods for the Examination of Water and Wastewater, American Public Health Association, American Water Works Association, Water Environment Federation, New York.

Ali, M., Sreekrishnan, T.R. 2001. Aquatic toxicity from pulp and paper mill effluents: A review, Adv. Environ. Res., 5: 175-196.

Dashtban, M., Schraft, H., Syed, T.A., Qin, W. 2010. Fungal biodegradation and enzymatic modification of lignin. Int. J. Biochem. Mol. Biol., 1: 36-50.

Thormann, M.N., Currah, R.S., Bayley, S.E. 2002. The relative ability of fungi from Sphagnum fuscum to decompose selected carbon substrates, Can. J. Microbiol., 48: 204-211.

Buyukkamaci, N., Koken, E. 2010. Economic evaluation of alternative wastewater treatment plant options for pulp and paper industry. Sci. Total Environ., 408: 6070-6078.

Lokeshwari, N., Srinikethan, G., Joshi, S.G., Inamdard, S., Srikanth, B., Bashirahmed, L., Sushma. 2013. Isolation of fungi for delignification of Pulp and Paper mill effluent, Int. J. Cur.Eng. Technol., 124-128.

Malaviya, P., Rathore, V.S. 2007. Bioremediation of pulp and paper mill effluent by a novel fungal consortium isolated from polluted soil, Bioresource Technol., 98: 3647-3651.

Ragunathan, R., Swaminathan, K. 2004. Biological treatment of a pulp and paper industry effluent by Pleurotus spp., World J. Microb. Biot., 20: 389393.

Raj, A., Kumara, S., Haqa, I., Singh, S.K. 2014. Bioremediation and toxicity 
reduction in pulp and paper mill effluent by newly isolated ligninolytic Paenibacillus sp., Ecolo. Eng., 71: 355-362.

Prasongsuk, S., Lotrakula, P., Imaib, T., Punnapayak, H. 2009. Decolourization of pulp mill wastewater using thermotolerant white rot fungi, Science Asia, 35: 37-41.

Sadasivam, S., Manickam, A. 2008. Biochemical method, 3rd ed., new age international, New Delhi, India.
Kumar, V., Dhall, P., Kumar, R., Singh, Y.P., Kumar, A. 2012. Bioremediation of agro-based pulp mill effluent by microbial consortium comprising autochthonous bacteria, Scientific World J., 1-7.

Bavendam, W. 1928. Uber das Vorkommen den Nachweis von Oxydasen beiholzzerstorenden. Pilzen Z. Pflanzenkrank. Pflanzenschutz, 38: 257-276.

\section{How to cite this article:}

Anand Barapatre and Harit Jha. 2016. Decolourization and Biological Treatment of Pulp and Paper Mill Effluent by Lignin-Degrading Fungus Aspergillus flavus Strain F10. Int.J.Curr.Microbiol.App.Sci. 5(5): 19-32. doi: http://dx.doi.org/10.20546/ijcmas.2016.505.003 